\title{
Recent advances in understanding and managing
}

\section{epidermolysis bullosa [version 1; peer review: 2 approved]}

\author{
Dimitra Kiritsi (i), Alexander Nyström
}

Department of Dermatology, Medical Center-University of Freiburg, Faculty of Medicine, 79104 Freiburg, Germany

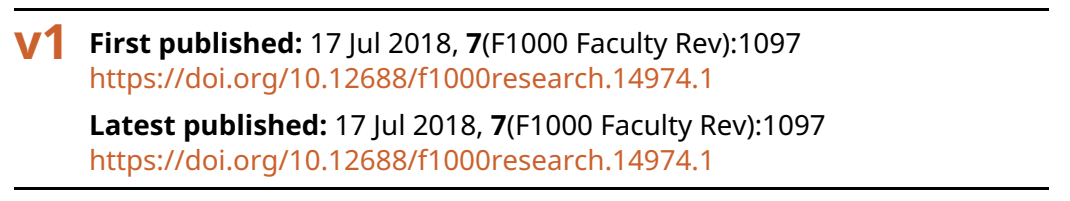

\section{Abstract}

Epidermolysis bullosa (EB) is a clinically and genetically heterogeneous skin fragility disorder characterized by trauma-induced skin dissociation and the development of painful wounds. So far, mutations in 20 genes have been described as being associated with more than 30 clinical EB subtypes. The era of whole-exome sequencing has revolutionized EB diagnostics with gene panels being developed in several EB centers and allowing quicker diagnosis and prognostication. With the advances of gene editing, more focus has been placed on gene editing-based therapies for targeted treatment. However, their implementation in daily care will still take time. Thus, a significant focus is currently being placed on achieving a better understanding of the pathogenetic mechanisms of each subtype and using this knowledge for the design of symptom-relief therapies, i.e. treatment options aimed at ameliorating and not curing the disease.

\section{Keywords}

skin fragility, collagen VII, laminin-332, gene therapy, TGF-b signaling

\section{Open Peer Review}

Approval Status

1

2

version 1

17 Jul 2018

Faculty Reviews are review articles written by the prestigious Members of Faculty Opinions. The articles are commissioned and peer reviewed before publication to ensure that the final, published version is comprehensive and accessible. The reviewers who approved the final version are listed with their names and affiliations.

1. Dedee Murrell, St George Hospital, University of New South Wales, Sydney, Australia

2. Gerhard Wiche, Perutz Laboratories, University of Vienna, Vienna, Austria Any comments on the article can be found at the end of the article. 
Corresponding author: Dimitra Kiritsi (dimitra.kiritsi@uniklinik-freiburg.de)

Author roles: Kiritsi D: Data Curation, Investigation, Methodology, Supervision, Writing - Original Draft Preparation, Writing - Review \& Editing; Nyström A: Funding Acquisition, Investigation, Writing - Original Draft Preparation, Writing - Review \& Editing

Competing interests: No competing interests were disclosed.

Grant information: DK's work has been supported by the German Research Foundation DFG (KI1795/1-1), EB Research Partnership, and the Mathilde-Wagner-Habilitationspreis from the University of Freiburg. AN has been supported by the German Research Foundation DFG (NY90/2-1, NY90/3-2), SFB850 project B11, and the Dystrophic Epidermolysis Bullosa Research Association (DEBRA). The funders had no role in study design, data collection and analysis, decision to publish, or preparation of the manuscript.

Copyright: ( $) 2018$ Kiritsi D and Nyström A. This is an open access article distributed under the terms of the Creative Commons Attribution License, which permits unrestricted use, distribution, and reproduction in any medium, provided the original work is properly cited.

How to cite this article: Kiritsi $D$ and Nyström A. Recent advances in understanding and managing epidermolysis bullosa [version 1; peer review: 2 approved] F1000Research 2018, 7(F1000 Faculty Rev):1097 https://doi.org/10.12688/f1000research.14974.1

First published: 17 Jul 2018, 7(F1000 Faculty Rev):1097 https://doi.org/10.12688/f1000research.14974.1 
Epidermolysis bullosa (EB) is a clinically and genetically heterogeneous skin fragility disorder characterized by traumainduced skin dissociation and the development of painful wounds ${ }^{1}$. Based on the ultrastructural split level, four main EB types exist: EB simplex (EBS) with an intraepidermal split, junctional EB (JEB) with separation within the lamina lucida, dystrophic EB (DEB) with sublamina densa separation, and Kindler syndrome with various split levels. So far, mutations in 20 genes have been described as being associated with more than 30 clinical EB subtypes ${ }^{2}$. This correlates with the complexity of the disease, since mutations within the same gene may cause more- or less-severe phenotypes of the disease with variable systemic manifestations complementing the skin manifestations. Mutations in the gene encoding collagen VII, for example, may cause only dystrophic nails, but they can also be associated with generalized blistering of the skin, severe scarring after healing of wounds, and numerous associated complications and organ manifestations ${ }^{3,4}$. To allow some prognostication, a thorough diagnosis is needed. This requires taking a skin biopsy and performing antibody-mediated staining for the proteins known to be associated with EB-a method called immunofluorescence mapping-or performing electron microscopy analysis. Both of these methods can be offered only by highly specialized EB centers. The era of whole-exome sequencing has revolutionized EB diagnostics with gene panels for EB being established in genetic departments, allowing a rapid and efficient diagnosis for patients with suspected $\mathrm{EB}^{5,6}$. Unfortunately, the treatment for individuals with EB is still symptomatic with implementation of modern wound care and treatment of the disease-associated complications ${ }^{7-9}$.

For years, research on EB has focused on identifying the disease-causing genes, allowing comprehensive classification of the clinical manifestations of each subtype and first approaches for the development of targeted therapies. The accessibility of the skin and the ability to expand epidermal stem cells in culture initially led to a focus on employing epidermal skin grafts for treatment. Major advancements have been made for these approaches. In 2006, an Italian research group was successful in achieving long-term engraftment of epidermal sheets generated from ex vivo, gene-corrected, autologous epidermal stem cells from a patient with JEB caused by $L A M B 3$ mutations ${ }^{10}$. Safety concerns regarding the use of retroviral vectors put subsequent studies on hold. However, these gene therapy efforts have recently been revived, and two publications from the research group, using the same approach of correction, have repeated the initial success of achieving long-term closure of chronic wounds ${ }^{11}$ as well as significantly advanced the treatment by successfully replacing $80 \%$ of the epidermis of a boy with laminin-332-deficient $\mathrm{JEB}^{12}$. DEB is caused by mutations in the collagen VII gene $(C O L 7 A 1)$ and characterized by blistering at the subluminal densa. Transplantation of epidermis generated from ex vivo corrected autologous keratinocytes has also shown promise in a clinical trial for the treatment of chronic wounds in DEB. Epidermal stem cells deficient in collagen VII were corrected by transduction of a retroviral vector carrying COL7Al as the transgene. Multiple wounds on four patients were treated, and for all patients initial healing of grafted wounds was observed ${ }^{13}$. However, there were indications that the benefit was less sustained than for laminin-332-deficient $\mathrm{JEB}^{13,14}$. The reasons for the differences still need to be clarified, but they could involve the basic biology of the proteins, with laminin-332 in skin being an epidermal product only and collagen VII being contributed by both the epidermis and the dermis ${ }^{14}$. Presently, direct in vivo mediated gene correction to the skin using a herpes simplex virus-1 vector is being developed for DEB. It has undergone late-phase pre-clinical studies, and clinical testing is being prepared.

Additional approaches using either allogeneic wild-type bonemarrow-derived stem cells ${ }^{15}$ or autologous spontaneously corrected epidermal stem cells, e.g. revertant mosaic patches, are possible therapeutic strategies that would not require gene engineering ${ }^{16}$.

With the advances of gene editing, together with the complex organization, regulation, and steps needed for the functional synthesis of extracellular matrix proteins associated with $\mathrm{EB}$, it is expected that more focus will be placed on gene editing-based therapies for targeted treatment. However, their implementation in daily care will still take time. Thus, a significant focus is currently being placed on achieving a better understanding of the pathogenetic mechanisms of each subtype and using this knowledge for the design of symptom-relief therapies, i.e. treatment options aimed at ameliorating and not curing the disease.

Patients with the most severe forms of DEB present with widespread blistering and the development of chronic, painful wounds. Healing occurs with the development of scars and fibrosis, leading to acral contractures and pseudosyndactyly ${ }^{17}$. Besides the skin, the mucosa is affected as well, and patients commonly suffer from esophageal stenoses with severe underweight and organ manifestations, including in the heart, liver, and kidney. We and others ${ }^{18-20}$ have recently shown that TGF- $\beta$ signaling activity is a major determinant of disease severity in DEB. DEB manifested differently in a monozygotic twin pair owing to the differential presence in their skin of decorin, a molecule known to trap TGF- $\beta^{20}$, making it inaccessible for signaling through its cognate receptors. In addition, elevated levels of FGF have been observed in individuals with recessive dystrophic EB $(\text { RDEB })^{21}$. This, together with the enhanced TGF- $\beta$, has been proposed to result in increased vascular density of RDEB skin ${ }^{22}$, thus creating a tumor-promoting microenvironment. An even further tumor-susceptible microenvironment is created by the bacterial overload and/or diversity loss of RDEB skin ${ }^{23,24}$, which is partially due to an insufficient innate immune response to bacteria ${ }^{4}$. Increased abundance of flagellated bacteria has been shown to be a mediator of wound-induced carcinogenesis ${ }^{25}$. Furthermore, studies have also suggested that bacteria are involved not only in the initiation of tumors but also in their conversion to a more aggressive and invasive phenotype ${ }^{26}$. Based on the elevated TGF- $\beta$ levels and activity in $\mathrm{DEB}^{27}$, as well as in the DEB mouse model, methods to target this therapeutically were sought. Losartan, an angiotensin II type 1 receptor antagonist, was fed to the DEB mouse model over a period of 
7 weeks, and the effects were compared to untreated mice ${ }^{18}$. A significant reduction of inflammation and skin fibrosis, halting the progression of pseudosyndactyly, was found in the treated mice. Based on these positive results, an investigatorinitiated clinical trial on the therapeutic relevance of losartan in DEB was initiated (REFLECT trial, EUDRACT number 2015003670-32). In addition, further safe and efficient molecules more directly targeting TGF- $\beta$ activity are currently under pre-clinical testing, and clinical trials are to be expected soon.

Besides using small molecules, biologic products are also able to act as disease modifiers. Particularly potent agents in this context are mesenchymal stromal cells (MSCs), which have shown promise as disease-ameliorating drugs in EB because of their strong anti-inflammatory abilities ${ }^{28-31}$. Since these cells are also natural producers of collagen VII, given at a sufficient dose, they may also restore protein abundance at the dermo-epidermal junction zone $\mathrm{e}^{29,32-35}$. Interestingly, recent advances have identified a subpopulation of dermal-derived MSCs with more potent, tissue-regenerative abilities ${ }^{36,37}$. Clinical trials using these socalled ABCB5-positive MSCs in improving wound healing in $\mathrm{DEB}$ are expected to be initiated later this year.

Another EB subtype with a pathogenesis-driven search for novel therapies is EBS. The presence of keratin intermediate aggregates in keratinocytes of patients with EBS due to mutations in the keratin 5 and 14 genes were reported some years ago ${ }^{38-40}$. Similarly, patients suffering from plectinopathy-associated EBS with muscular dystrophy (EBS-MD) and mice lacking plectin in skeletal muscle display pathological desmin-positive protein aggregation. The group around Gerhard Wiche used the chemical chaperone 4-phenylbutyrate to treat muscle-specific, plectin-deficient mice and plectin-deficient myotubes, showing remarkable amelioration of the pathological phenotypes ${ }^{41}$. 4phenylbutyrate is an approved orphan drug, which is used to treat urea cycle disorders, as its metabolites offer an alternative pathway to allow the excretion of excess nitrogen. However, it has been tested not only in the urea cycle but also in other inherited disorders and was determined to be effective in progressive familial intrahepatic cholestasis ${ }^{42}$; trials are ongoing for spinal muscular atrophy or thalassemia. The drug's presumed mechanisms of action possibly include reduction of cellular stress and regulation of autophagy. Thus, the use of chaperones in EBS is currently being sought by several groups. In addition and possibly related to the pathogenic cellular aggregates, efforts are being made to target IL1 $\beta$ in EBS due to keratin mutations, since it has been shown to play a pathogenetic role in this EB subtype ${ }^{43}$.

Although several clinical trials have now been initiated for individuals with $\mathrm{EB}$, the treatment of the disease in most cases still remains symptomatic and based on preventive measures, together with symptomatic treatment of cutaneous and extracutaneous manifestations ${ }^{4}$ and complications. A multidisciplinary team of experts from different European EB centers has prepared recommendations, grounded on available literature and expert opinion. They have been subsequently revised by a panel of external experts, using an online-modified Delphi method to generate consensus. The optimal management of patients is a prerequisite for them to benefit from the specific treatments that currently are under development ${ }^{7}$. What has become apparent from the clinical studies conducted so far in EB is the lack of good data on natural history and disease severity biomarkers. As a substitute, excellent work on scoring the clinical severity of the disease has in some cases been used so far ${ }^{44-47}$.

\section{Abbreviations}

DEB, dystrophic epidermolysis bullosa; EB, epidermolysis bullosa; EBS, epidermolysis bullosa simplex; JEB, junctional epidermolysis bullosa; MSCs, mesenchymal stromal cells; RDEB, recessive dystrophic epidermolysis bullosa; TGF, transforming growth factor

\section{Competing interests}

The authors declare that they have no competing interests.

\section{Grant information}

DK's work has been supported by the German Research Foundation DFG (KI1795/1-1), EB Research Partnership, and the Mathilde-Wagner-Habilitationspreis from the University of Freiburg. AN has been supported by the German Research Foundation DFG (NY90/2-1, NY90/3-2), SFB850 project B11, and the Dystrophic Epidermolysis Bullosa Research Association (DEBRA).

The funders had no role in study design, data collection and analysis, decision to publish, or preparation of the manuscript.
1. Bruckner-Tuderman L: Dystrophic epidermolysis bullosa: pathogenesis and clinical features. Dermatol Clin. 2010; 28(1): 107-14. PubMed Abstract | Publisher Full Text

2. F Fine JD, Bruckner-Tuderman L, Eady RA, et al:: Inherited epidermolysis bullosa: updated recommendations on diagnosis and classification. J Am Acad Dermatol. 2014; 70(6): 1103-26.

PubMed Abstract | Publisher Full Text | F1000 Recommendation

3. Fine JD, Mellerio JE: Extracutaneous manifestations and complications of inherited epidermolysis bullosa: part II. Other organs. J Am Acad Dermatol. 2009; 61(3): 387-402; quiz 403-4.

PubMed Abstract | Publisher Full Text

4. Nyström A, Bornert O, Kühl T, et al:: Impaired lymphoid extracellular matrix impedes antibacterial immunity in epidermolysis bullosa. Proc Natl Acad Sci US A. 2018; 115(4): E705-E714.

PubMed Abstract | Publisher Full Text | Free Full Text

5. F Vahidnezhad H, Youssefian L, Saeidian AH, et al:: Genome-wide single 
nucleotide polymorphism-based autozygosity mapping facilitates identification of mutations in consanguineous families with epidermolysis bullosa. Exp Dermatol. 2018.

PubMed Abstract | Publisher Full Text | F1000 Recommendation

6. F Tenedini E, Artuso L, Bernardis I, et al.: Amplicon-based next-generation sequencing: an effective approach for the molecular diagnosis of epidermolysis bullosa. Br J Dermatol. 2015; 173(3): 731-8. PubMed Abstract | Publisher Full Text | F1000 Recommendation

7. F El Hachem M, Zambruno G, Bourdon-Lanoy E, et al:: Multicentre consensus recommendations for skin care in inherited epidermolysis bullosa. Orphanet $J$ Rare Dis. 2014; 9: 76

PubMed Abstract | Publisher Full Text | Free Full Text | F1000 Recommendation

8. Chiaverini $\mathrm{C}$, Bourrat $\mathrm{E}$, Mazereeuw-Hautier $\mathrm{J}$, et al.: [Hereditary epidermolysis bullosa: French national guidelines (PNDS) for diagnosis and treatment]. Ann Dermatol Venereol. 2017; 144(1): 6-35. PubMed Abstract | Publisher Full Tex

9. $\quad \mathrm{F}$ Hsu CK, Wang SP, Lee JY, et al:: Treatment of hereditary epidermolysis bullosa: updates and future prospects. Am J Clin Dermatol. 2014; 15(1): 1-6. PubMed Abstract | Publisher Full Text | F1000 Recommendation

10. F Mavilio F, Pellegrini G, Ferrari S, et al.: Correction of junctional epidermolysis bullosa by transplantation of genetically modified epidermal stem cells. Nat Med. 2006; 12(12): 1397-402. PubMed Abstract | Publisher Full Text | F1000 Recommendation

11. F Bauer JW, Koller J, Murauer EM, et al:: Closure of a Large Chronic Wound through Transplantation of Gene-Corrected Epidermal Stem Cells. J Invest Dermatol. 2017; 137(3): 778-81.

PubMed Abstract | Publisher Full Text | F1000 Recommendation

12. $\mathrm{F}$ Hirsch $\mathrm{T}$, Rothoeft $\mathrm{T}$, Teig $\mathrm{N}$, et al.: Regeneration of the entire human epidermis using transgenic stem cells. Nature. 2017; 551(7680): 327-32. PubMed Abstract | Publisher Full Text | F1000 Recommendation

13. F Siprashvili Z, Nguyen NT, Gorell ES, et al:: Safety and Wound Outcomes Following Genetically Corrected Autologous Epidermal Grafts in Patients With Recessive Dystrophic Epidermolysis Bullosa. JAMA. 2016; 316(17): 1808-17. PubMed Abstract | Publisher Full Text | F1000 Recommendation

14. Nyström A, Bruckner-Tuderman L: Gene Therapy for Epidermolysis Bullosa: Sticky Business. Mol Ther. 2016; 24(12): 2035-6. PubMed Abstract | Publisher Full Text | Free Full Text

15. F Vanden Oever M, Twaroski K, Osborn MJ, et al:: Inside out: regenerative medicine for recessive dystrophic epidermolysis bullosa. Pediatr Res. 2018; 83(1-2): 318-24

PubMed Abstract | Publisher Full Text | F1000 Recommendation

16. Gostyński A, Pasmooij AM, Jonkman MF: Successful therapeutic transplantation of revertant skin in epidermolysis bullosa. J Am Acad Dermatol. 2014; 70(1): 98-101.

PubMed Abstract | Publisher Full Text

17. F Kern JS, Grüninger G, Imsak R, et al:: Forty-two novel COL7A1 mutations and the role of a frequent single nucleotide polymorphism in the MMP1 promoter in modulation of disease severity in a large European dystrophic epidermolysis bullosa cohort. Br J Dermatol. 2009; 161(5): 1089-97. PubMed Abstract | Publisher Full Text | F1000 Recommendation

18. Nyström A, Thriene K, Mittapalli V, et al:: Losartan ameliorates dystrophic epidermolysis bullosa and uncovers new disease mechanisms. $E M B O \mathrm{MOl}$ Med. 2015; 7(9): 1211-28.

PubMed Abstract | Publisher Full Text | Free Full Text

19. Thriene K, Grüning BA, Bornert $O$, et al: Combinatorial Omics Analysis Reveals Perturbed Lysosomal Homeostasis in Collagen VII-deficient Keratinocytes. Mol Cell Proteomics. 2018; 17(4): 565-79.

PubMed Abstract | Publisher Full Text | Free Full Text

20. F Odorisio T, Di Salvio M, Orecchia A, et al:: Monozygotic twins discordant for recessive dystrophic epidermolysis bullosa phenotype highlight the role of TGF- $\beta$ signalling in modifying disease severity. Hum Mol Genet. 2014; 23(15): 3907-22.

PubMed Abstract | Publisher Full Text | F1000 Recommendation

21. Arbiser JL, Fine JD, Murrell D, et al.: Basic fibroblast growth factor: a missing link between collagen VII, increased collagenase, and squamous cell carcinoma in recessive dystrophic epidermolysis bullosa. Mol Med. 1998; 4(3) 191-5.

PubMed Abstract | Free Full Text

22. Martins VL, Caley MP, Moore K, et al:: Suppression of TGF $\beta$ and Angiogenesis by Type VII Collagen in Cutaneous SCC. J Natl Cancer Inst. 2016; 108(1): pii: djv293.

PubMed Abstract | Publisher Full Text

23. van der Kooi-Pol MM, Duipmans JC, Jonkman MF, et al:: Host-pathogen interactions in epidermolysis bullosa patients colonized with Staphylococcus aureus. Int J Med Microbiol. 2014; 304(2): 195-203.

PubMed Abstract | Publisher Full Text

24. Fuentes I, Guttmann-Gruber C, Ling Tay AS, et al:: Reduced microbial diversity is a feature of recessive dystrophic epidermolysis bullosa involved skin and wounds. J Invest Dermatol. 2018; pii: S0022-202X(18)31963-8. PubMed Abstract | Publisher Full Text

25. F Hoste E, Arwert EN, Lal R, et al.: Innate sensing of microbial products promotes wound-induced skin cancer. Nat Commun. 2015; 6: 5932. PubMed Abstract | Publisher Full Text | Free Full Text | F1000 Recommendation

26. Föll MC, Fahrner M, Gretzmeier C, et al.: Identification of tissue damage, extracellular matrix remodeling and bacterial challenge as common mechanisms associated with high-risk cutaneous squamous cell carcinomas. Matrix Biol. 2018; 66: 1-21.

PubMed Abstract | Publisher Full Text

27. F Nyström A, Velati D, Mittapalli VR, et al:: Collagen VII plays a dual role in wound healing. J Clin Invest. 2013; 123(8): 3498-509.

PubMed Abstract | Publisher Full Text | Free Full Text | F1000 Recommendation

28. F Petrof G, Lwin SM, Martinez-Queipo M, et al.: Potential of Systemic Allogeneic Mesenchymal Stromal Cell Therapy for Children with Recessive Dystrophic Epidermolysis Bullosa. J Invest Dermatol. 2015; 135(9): 2319-21. PubMed Abstract | Publisher Full Text | Free Full Text | F1000 Recommendation

29. Kühl T, Mezger M, Hausser I, et al:: High Local Concentrations of Intraderma MSCs Restore Skin Integrity and Facilitate Wound Healing in Dystrophic Epidermolysis Bullosa. Mol Ther. 2015; 23(8): 1368-79. PubMed Abstract | Publisher Full Text | Free Full Text

30. F Wagner JE, Ishida-Yamamoto A, McGrath JA, et al.: Bone marrow transplantation for recessive dystrophic epidermolysis bullosa. $N$ Engl $\mathrm{J}$ Med. 2010; 363(7): 629-39.

PubMed Abstract | Publisher Full Text | Free Full Text | F1000 Recommendation

31. Tamai K, Uitto J: Stem Cell Therapy for Epidermolysis Bullosa-Does It Work? J Invest Dermatol. 2016; 136(11): 2119-21. PubMed Abstract | Publisher Full Text

32. F Ganier C, Titeux M, Gaucher S, et al.: Intradermal Injection of Bone Marrow Mesenchymal Stromal Cells Corrects Recessive Dystrophic Epidermolysis Bullosa in a Xenograft Model. J Invest Dermatol. 2018; pii: S0022-202X(18)31965-1. PubMed Abstract | Publisher Full Text |F1000 Recommendation

33. Kühl T, Mezger M, Hausser I, et al.: Collagen VII Half-Life at the DermalEpidermal Junction Zone: Implications for Mechanisms and Therapy of Genodermatoses. J Invest Dermatol. 2016; 136(6): 1116-23. PubMed Abstract | Publisher Full Text

34. F Conget $\mathrm{P}$, Rodriguez $\mathrm{F}$, Kramer S, et al.: Replenishment of type VII collagen and re-epithelialization of chronically ulcerated skin after intradermal administration of allogeneic mesenchymal stromal cells in two patients with recessive dystrophic epidermolysis bullosa. Cytotherapy. 2010; 12(3): 429-31. PubMed Abstract | Publisher Full Text | F1000 Recommendation

35. linuma S, Aikawa E, Tamai K, et al:: Transplanted bone marrow-derived circulating PDGFR $\alpha^{+}$cells restore type VII collagen in recessive dystrophic epidermolysis bullosa mouse skin graft. J Immunol. 2015; 194(4): 1996-2003. PubMed Abstract | Publisher Full Text | Free Full Text

36. F Webber BR, O'Connor KT, McElmurry RT, et al:: Rapid generation of Col7a $1^{-1}$ mouse model of recessive dystrophic epidermolysis bullosa and partial rescue via immunosuppressive dermal mesenchymal stem cells. $L a b$ Invest. 2017; 97(10): 1218-24.

PubMed Abstract | Publisher Full Text | Free Full Text | F1000 Recommendation

37. $\mathrm{F}$ Schatton $\mathrm{T}$, Yang J, Kleffel $\mathrm{S}$, et al:: $\mathbf{A B C B} 5$ Identifies Immunoregulatory Dermal Cells. Cell Rep. 2015; 12(10): 1564-74.

PubMed Abstract | Publisher Full Text | Free Full Text | F1000 Recommendation

38. Chamcheu JC, Navsaria H, Pihl-Lundin I, et al.: Chemical chaperones protect epidermolysis bullosa simplex keratinocytes from heat stress-induced keratin aggregation: involvement of heat shock proteins and MAP kinases. $J$ Invest Dermatol. 2011; 131(8): 1684-91. PubMed Abstract | Publisher Full Text

39. Löffek S, Wöll S, Höhfeld J, et al:: The ubiquitin ligase CHIP/STUB1 targets mutant keratins for degradation. Hum Mutat. 2010; 31(4): 466-76. PubMed Abstract | Publisher Full Text

40. Bergman R, Harel A, Sprecher E: Dyskeratosis as a histologic feature in epidermolysis bullosa simplex-Dowling Meara. J Am Acad Dermatol. 2007; 57(3): 463-6.

PubMed Abstract | Publisher Full Text

41. F Winter L, Staszewska I, Mihailovska E, et al:: Chemical chaperone ameliorates pathological protein aggregation in plectin-deficient muscle. J Clin Invest. 2014; 124(3): 1144-57.

PubMed Abstract | Publisher Full Text | Free Full Text | F1000 Recommendation

42. $\mathrm{F}$ Naoi $\mathrm{S}$, Hayashi $\mathrm{H}$, Inoue $\mathrm{T}$, et al.: Improved liver function and relieved pruritus after 4-phenylbutyrate therapy in a patient with progressive familial intrahepatic cholestasis type 2 . J Pediatr. 2014; 164(5): 1219-1227.e3. PubMed Abstract | Publisher Full Text | F1000 Recommendation

43. Wally $\mathrm{V}$, Lettner $\mathrm{T}$, Peking $\mathrm{P}$, et al.: The pathogenetic role of IL-1 $\beta$ in severe epidermolysis bullosa simplex. J Invest Dermatol. 2013; 133(7): 1901-3. PubMed Abstract | Publisher Full Text

44. Frew JW, Martin LK, Nijsten T, et al:: Quality of life evaluation in epidermolysis 
bullosa (EB) through the development of the QOLEB questionnaire: an EB-specific quality of life instrument. Br J Dermatol. 2009; 161(6): 1323-30. PubMed Abstract | Publisher Full Text

45. F Loh CC, Kim J, Su JC, et al:: Development, reliability, and validity of a nove Epidermolysis Bullosa Disease Activity and Scarring Index (EBDASI). J Am Acad Dermatol. 2014; 70(1): 89-97.e1-13.

PubMed Abstract | Publisher Full Text | F1000 Recommendation
46.

Moss C, Wong A, Davies P: The Birmingham Epidermolysis Bullosa Severity score: development and validation. Br J Dermatol. 2009; 160(5): 1057-65.

PubMed Abstract | Publisher Full Tex

47. F Schwieger-Briel A, Chakkittakandiyil A, Lara-Corrales I, et al.: Instrument for scoring clinical outcome of research for epidermolysis bullosa: a consensusgenerated clinical research tool. Pediatr Dermatol. 2015; 32(1): 41-52.

PubMed Abstract | Publisher Full Text | F1000 Recommendation 


\section{Open Peer Review}

\section{Current Peer Review Status:}

\section{Editorial Note on the Review Process}

Faculty Reviews are review articles written by the prestigious Members of Faculty Opinions. The articles are commissioned and peer reviewed before publication to ensure that the final, published version is comprehensive and accessible. The reviewers who approved the final version are listed with their names and affiliations.

\section{The reviewers who approved this article are:}

\section{Version 1}

\section{Gerhard Wiche}

Department of Biochemistry \& Cell Biology, Perutz Laboratories, University of Vienna, Vienna, Austria Competing Interests: No competing interests were disclosed.

\section{Dedee Murrell}

Department of Medicine, St George Hospital, University of New South Wales, Sydney, Australia

Competing Interests: No competing interests were disclosed.

The benefits of publishing with F1000Research:

- Your article is published within days, with no editorial bias

- You can publish traditional articles, null/negative results, case reports, data notes and more

- The peer review process is transparent and collaborative

- Your article is indexed in PubMed after passing peer review

- Dedicated customer support at every stage

For pre-submission enquiries, contact research@f1000.com 